\title{
An Empirical Study on the Cooperative Pattern of Practical Education in Colleges and Universities from the Perspective of Econiche
}

\author{
Bei ZHU \\ Student Affairs Department \\ Shanghai University of Engineering Science \\ Shanghai,China \\ E-mail:zhubei1124@126.com
}

\author{
Jia-Jie WANG \\ Committee of Communist Youth League \\ Shanghai University of Engineering Science \\ Shanghai,China \\ E-mail:ep28@163.com
}

\begin{abstract}
From the perspective of econiche, this article analyzes the significance of the practical education work in colleges and universities and the outstanding problems existing now in three aspects. It is pointed out that breaking through the bottleneck through cooperation is the key to the development of educational work .This article introduces the econiche concept and its important contact with the practice of educating people. And it combines with the cases of "Large Class of Knowing and Doing" in Shanghai University of Engineering Science to focus on the thinking of university's practical education of coordinated development strategy from the perspective of econiche theory.
\end{abstract}

Keywords-econiche, practical education, cooperative pattern, empirical study

The outline of the national medium and long term educational reform and development plan (2010-2020) puts forward new requirements for the cultivation of students' creative spirit and practical ability. It is an important task for colleges and universities to promote the work of practical education and cultivate the qualified builders and reliable successors of the cause of socialism with Chinese characteristics.

\section{The OUtstanding Problems of the Practical EDUCATION IN COLLEGES AND UNIVERSITIES}

\section{A. The Content of Education Is Out of Touch and the Formalism Is Obvious}

Some colleges' and universities' educational content of the top-level design is not perfect, but just for the "activity" to complete the task. The practical activities lack the theoretical basis and the educational significance. There are also some colleges and universities will treat practical education as a face project, and they do not make the practice of educating people into the human body system. The degree of attention is not enough, and the theory and practical education are not linked, which have resulted in the "formalism".

\section{B. The Main Body of Education Is Single, And Internal and} External Resources Are Idle

Some colleges' and universities' practical education always "close the door to do". The inside schools limit in the school work line, and the Communist Youth League line "play by themselves". They just lead students to walk and visit out of schools. They ignore the coordination and integration of all kinds of resources in and out of schools, which restrict the improvement of the educational connotation, the strengthening of the education teachers and the enhancing of the educational experience.

\section{The Forms of Education Are Backward, and the Creative Thinking Is in Shortage}

Some colleges and universities can't keep up with the pace of the practical education's forms, and they only limit to traditional activities, so student interaction, sense of participation, sense of access is not strong, and the enthusiasm of learning is reducing.

\section{The Synergetic Trend of Practical Education}

These outstanding problems greatly reduce the competitiveness of the pattern of practical education, so that the practical education cannot play an effective role in guiding and educating people. In the final analysis, the key to solve these problems lies in the construction of the cooperative pattern of practical education.

\section{THE INTRODUCTION AND SPECIFIC CONNOTATION OF ECONICHE THEORY}

\section{A. What Is "Econiche"}

In ecology, econiche is defined as the position and role of species in the biological community, and the spatial position, the function and the role of the biological population in the ecosystem. Econiche theory is an important theory for ecology to study the competition among species, the adaptability of species to the environment, the diversity and stability of ecosystems.

\section{B. "Econiche" Theory and the Practical Education in Colleges and Universities}

The econiche of practical education in colleges and universities can be defined as the interaction between the practical education and the environment, the internal and external school resources and other universities. The relative status, function and role of the practical education in colleges and universities are formed in this process. The foothold is the maximization of resources and competitive relations, especially the external campus resources. 


\section{AN EMPIRICAL CASE ON THE COOPERATIVE PATTERN OF PRACTICAL EDUCATION IN COLLEGES AND UNIVERSITIES FROM THE PeRsPeCtIVE OF ECONICHE-- LARGE Class OF KNOWING AND DOING}

\section{A. What Is the "Large Class of Knowing and Doing"}

"Large Class of Knowing and Doing" is a kind of full -open universities ideological and political education pattern. "Knowing" refers to the ideal and faith education for college students focusing on the ideological and political education. 'Doing: refers to the college students' social practical education which concentrates on industry-school collaboration.

\section{B. The Characteristics of "Large Class of Knowing and Doing"}

The characteristics of the practical education pattern of "Large Class of Knowing and Doing "can be summarized as the following aspects:

1) System Design Highlights the Connotation of Educ ation in the Training Mode of Innovative Talents

"Large Class of Knowing and Doing" pays attention to the top-level design of the school level, rather than a simple implementation of a practical activity. So we should pay attention to the compatibility of ideological and political education and practical activities, and seek the blending point of the first class to the second class to realize the unity of learning and thinking, and knowing and doing.

2) Abutment Demand Increases Strength in the Realiz ation of Talent Employment and Entrepreneurship

One of the footholds of practical education is to cultivate high quality talents. Especially in the "public venture, highly innovative "era, how to strengthen the training of innovation talents is particularly important. "Large Class of Knowing and Doing" focuses on the social experience about the unity of knowing and doing, letting students know in the process of social practice in the combination of professional knowledge, and acquire knowledge in relatively easy way.

3) Cultural Integration Extends Educational Space W hen Achieving Social Coordination

Through the "Large Class of Knowing and Doing", schools, governments, social enterprises, and social organizations support and carry out ideological and political education, making different culture interact with each other, and have seamless abutment.

\section{REFLECTIONS ON THE DEVELOPMENT STRATEGY OF College Students' COOPERATIVE PATTERn OF PRACTICAL EDUCATION BASED ON ECONICHE THEORY}

\section{A. Clear the Direction of Development, and Achieve Dislocation Competition}

Because of the same region, resource quantity and production rate is fixed. If we strongly touch and rob, we will easy to lose. Different types of colleges and universities can occupy some resources through separation of them, which can be based on econiche differentiation strategy to implement and formulate a long-term development strategy according to their actual situation.

\section{B. Enrich the Concept of Cooperation and Achieve the Expansion of Competition}

In the process of education in colleges and universities, we can strengthen the competition by means of multi cooperation model. Coordination contains the coordinated teaching resources between first class and second class, the coordinated practice of teaching among cooperative government, enterprises, and social organizations, the coordinated teaching between traditional theory teaching and new media practice of participative teaching form, and the coordinated development between teachers at schools and teachers outside schools etc.

\section{Improve Internal Mechanisms and Achieve Long-Term Competition}

Long-term competition refers to the realization of the long- term competition effect in the process of acquiring and transforming the educational resources. It needs to improve the mechanism system. The internal mechanism of practical education includes university collaboration pattern rules, making collaborative education into the talent training scheme, the mechanism support for the optimal allocation of internal and external collaborative resources and practical education's evaluation mechanism etc.

\section{CONCLUSION}

From the point of view of ecology to analyze the future development of practical education, we can further refine the work of colleges and universities, to build a more perfect system of core competitiveness of colleges and universities. In the fierce competition to maintain sustainable development, access to a win-win situation.

\section{REFERENCES}

[1] The niche concept revisited: mechanistic models and community context. Leibold M A. Ecology . 1995

[2] Core competence and education[J] . Gary Holmes,Nick Hooper. Higher Education . 2000 (3)

[3] The niche concept: Suggestions for its use in human ecology[J] Donald L. Hardesty. Human Ecology . 1975 (2) 